AL-AZHAR UNIVERSITY BULLETIN OF THE FACULTY OF

LANGUAGES \& TRANSLATION

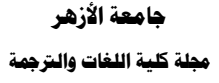

The (Mis)use of Paratexts in Edip Yuksel's English Translation of the Meanings of the Glorious Qur'an

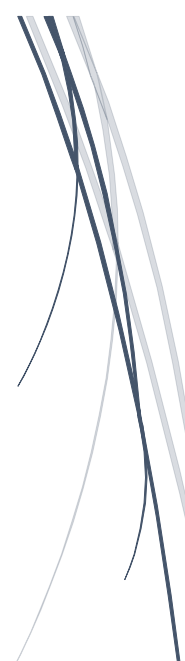

Abdelaziz Fouad Saad

Assistant Lecturer at the Department of English, Faculty of Languages and Translation, Al-Azhar University 


\section{The (Mis)use of Paratexts in Edip Yuksel's English Translation of the Meanings of the Glorious Qur'an}

Abdelaziz Fouad Saad

Department of English Language, Faculty of Languages and Translation, Al-Azhar University, Cairo, Egypt.

Email: abdelazizfouad.2010@azhar.edu.eg

\section{Abstract:}

This paper aims at analyzing paratexts in the translation of the meanings of the Glorious Qur'an entitled Quran: A Reformist Translation by Edip Yuksel, Layth Saleh alShaiban, and Martha Schulte-Nafeh. It attempts to explore how the translators exploit paratexts to bring too many ideas unrelated to those implied in the main text but remain blind to illustrate the real intended ones. It seeks evidencing how the translators delude themselves in suggesting that their approach is the only way to read the meanings of the Glorious Qur'an. Furthermore, the paper highlights how paratexts are used for purpose of exploitation instead of exploration. It addresses four forms of paratexts used in the selected data: title of the selected data; preface or prefatory introduction; intertitles; and endnotes. The paper aims at showing how these paratexts affect the way in which the original themes are reframed to make them compatible with the translators' targeted paradigm. Specifically, it describes how the translators combine new innovated concepts with contested ones waging a war on the social, religious and cultural world of all the people who oppose the translators' approach. The present paper addresses how the translators attempt to secure predominance and prevailing influence on minds of the target readers by constructing a number of new frames in the target text driving them to a certain interpretation of the Qur'anic text.

Key words: paratexts, preface, title, intertitle, endnote

\section{الاستخدام الخاطئ للنصوص الموازية في ترجمة إديب يوكسل الإنجليزية}

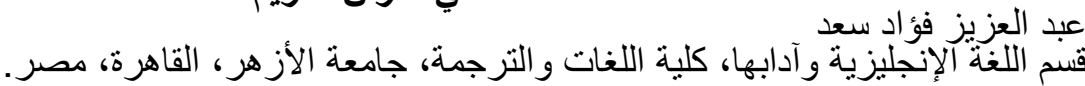
البريد الإلكتروني: abdelazizfouad.2010@azhar.edu.eg

يدور هذا البحث حول بيان استخدام النصوص الموازية في إحدى ترجمات معاني القرآن الكريم وعنوانها القرآن: ترجمة

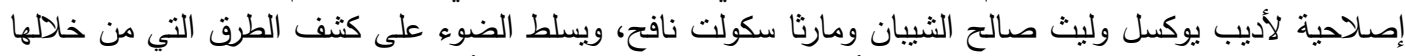

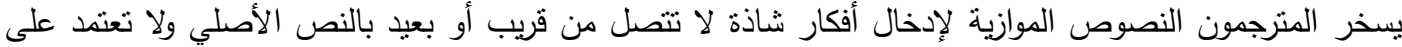

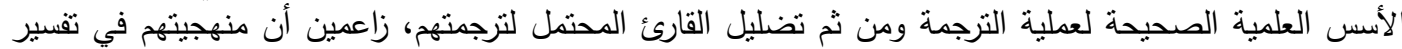

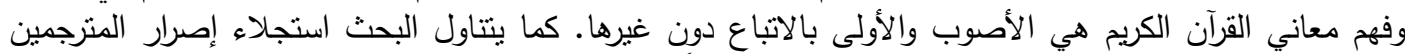

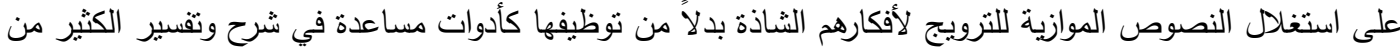

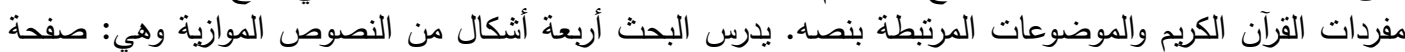

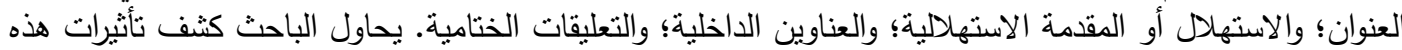

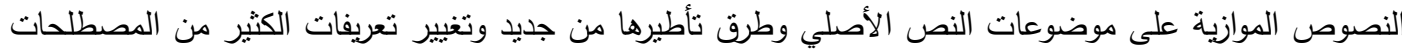

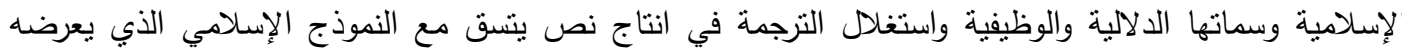

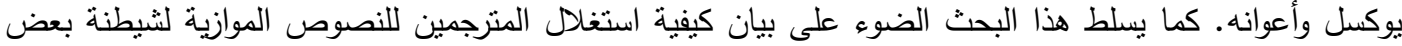

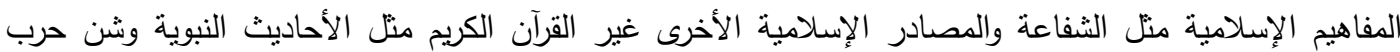

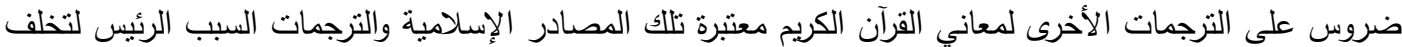

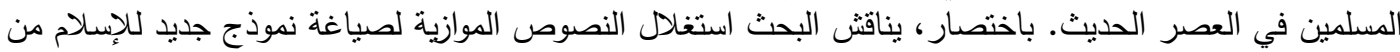
منظور يوكسل وأعوانه.

الكلمات المفتاحية: النصوص الموازية؛ صفحة العنوان؛ الاستهلال؛ العناوين الداخلية؛ التعليقات الختامية Abbreviations

QART:

Quran: A Reformist Translation 


\section{Introduction}

At the outset, Genette defines paratexts as "those liminal devices and conventions, both within the book (peritext) and outside it (epitext), that mediate the book to the reader: titles and subtitles, pseudonyms, forewords, dedications, epigraphs, prefaces, intertitles, notes, epilogues, and afterwords" (xviii). He adds that all "paratexts" are also extra-textual elements which surround and enable any text to "become a book and to be offered as such to its readers, and more generally to the public" (1). As for the temporal occasions of "epitexts", Genette states that they may include such elements which precede or come later to the specific work (5).

Together with the main text, paratexts have influence on the reception and understanding of the main text by the target readers. Sometimes paratexts accrue the same significance of the main text. In translation, "paratexts provide the necessary conceptual information that is necessary for the reader to understand the translated text better" (Veisbergs, 75). It is through paratextual strategies that translators can "insert their own critical comments and glosses at various points" because they allow the translators to "signal their position in relation to the narrative in question" (Baker, 128).

In order to achieve a "better reception and pertinent reading of the text", a translator is usually required to highlight certain elements in his/her work. It is inevitable that "only selected elements could be highlighted, while others have to be suppressed or even lost" due to impossibility of covering "all aspects of a text in the paratexts." This process of 'selectivity' enables a translator to "situate his/her work within a specific framework and to guide the reader towards a specific context. This element of 'selectivity' is an important feature of the paratexts since it allows us to understand the translator's goals, choices and position" (Hassen, 107).

Through paratexts, translators can "actively reframe the immediate narrative as well as the larger narratives in which it is embedded by careful realignment of participants in time and social/political space." Such paratextual elements are "among the numerous sites available to translators for repositioning themselves, their readers and other participants in time and space." Sometimes, translators prefer to use paratextual elements to configure "the immediate relationship between the reader and the community depicted in the source narrative." In making such paratextual additions, "the translator's work ceases to be translating and becomes commentary" (Baker, 132-135). Paratexts are composed of explicit statements which are used by a translator to draw a distinction between his/her voice and the 
voice of the source text's author and to include information he/she considers to be of considerable significance for the reader but cannot be contained in the main text for any reason. A translator uses paratexts to make his/her voice heard and hence leaving his/her invisible position to talk to the reader directly (Buendia, 150).

It is therefore usually necessary to complement a translation with paratextual elements such as footnotes, particularly in the case of basic cultural differences between the source community and target community as well as in the case of special linguistic devices used in the original text (for example, puns). Footnotes may also be necessary or desirable in some unusual circumstances, for example, if there are some serious factual errors in the source text. At the same time, they may provide "encyclopedic information concerning the source culture". Thus, such paratextual elements "introduce the reader into certain translation problems or the intricacies of the translator's works" and "should appear first of all in special annotated editions of great works" (Hejwowski, 227). Hejwowski comes to argue that paratextual elements should be used as an explanatory technique stating, "When adding footnotes, the translator should not replace the reader and deprive him or her of any mental effort; footnotes' main aim should not be a display of the translators' erudition" (230).

In translation of the meanings of the Glorious Qur'an, paratextual elements can be used usually to illustrate the historical significance of any qur'anic word or concept. A footnote or even an extended commentary can be employed, according to Nassimi, as "a torch that penetrate the fog of both language and culture-specific religious words and concepts; by doing so, one can guarantee that at least some misconceptions diminish. Footnotes can provide the target readers with a more accurate historical and exegetical perspective." They are substantial for the target language reader to highlight the various linguistic, rhetorical, and cultural backgrounds of the qur'anic discourse (71).

Additionally, a translator uses paratextual elements to avoid paraphrasing or over-translation in the main text of the Qur'an as a sensitive text. Such tools are as well used to enforce the process of communication between the source text and the target reader. They are useful for comprehension of the text of the Qur'an (AbdulRaof, 139).

Paratexts are therefore important key elements ought to be used by translators to provide an accurate and unambiguous translated version of the Glorious Qur'an. Endnotes, for instance, are used almost at the end of each chapter (Surah) in the selected translation of the meanings of the Glorious Qur'an. 


\section{The Selected Data and the Translators}

The selected data entitled Quran: A Reformist Translation, published in 2015, was made by Edip Yuksel, Layth Saleh al-Shaiban, and Martha Schulte-Nafeh. Yuksel is an American-Turkish author and progressive activist who spent four years in Turkish prisons in 1980s for his political writings that promoted an Islamic revolution in Turkey. He is a reformed Muslim or a rational monotheist. He is the author of over twenty books and hundreds of articles on religion, politics, philosophy and law in Turkish and English. Yuksel has organized international Critical Thinkers for Islamic Reform Conferences in Atlanta, Oxford, Los Angeles, and Istanbul. He is the founder of Islamic Reform Organization and co-founder of Muslims for Peace, Justice and Progress (Quran 4).

Layth Saleh al-Shaiban is an author of various books and articles on Islam, founder of Progressive Muslims, and co-founder of Islamic Reform Organization. Layth works in a financial institution as a financial adviser. He lives in Saudi Arabia. As for Martha Schulte-Nafeh, she is an Assistant Professor of Practice at the University of Arizona and Language Coordinator of Middle Eastern Languages at the Department of Near Eastern Studies. In 1982, she taught English as a Foreign Language at American University in Cairo, Egypt. She received her Ph.D. from University of Arizona in Near Eastern Studies- Arabic Language and Linguistics in 2004 (Quran 4).

\section{Aim of the Study}

This paper aims at analyzing how the translators exploit paratexts to manipulate the original text and hence insert too many innovated ideas different from those implied in the main text. To put it another way, it attempts to explore how paratexts are used by the translators to shape a new image of the Qur'anic text highlighting how paratexts are used for purpose of exploitation instead of exploration. It also seeks evidencing how the translators delude themselves in suggesting that their approach is the only proper way to interpret the Glorious Qur'an. The study illustrates how paratexts affect the way in which the original themes are reframed according to the translators' views. It also aims at exploring how paratexts are exploited by the translators to fiercely attack the traditional paradigm of Islam and openly criticize other translations of the meanings of the Glorious Qur'an. 


\section{Methodology and Analysis}

The present paper attempts to provide an analysis of the purposes and functions of some paratextual elements exploited by the translators and discusses whether they use such elements for purposes of clarification or not. The analysis is grounded mainly on the paratextual approach proposed by Genette in his book entitled Paratexts: Thresholds of Interpretation. The paper investigates the selected data's title, preface, intertitles, and endnotes. The researcher follows the MLA (Modern Language Association of America) Handbook for Writers of Research Papers, Seventh Edition, New York, 2009.

\subsection{Title of the Selected Translation}

Actually, titles of the translated works perform a very important role. Baker states that titles can be used very effectively to "(re)frame narratives in translation" and hence often accompanied by "subtle shifts in the texts themselves, in line with the narrative position signaled in the new title" (129-130). Genette comes up with three functions of titles: "to identify the work"; "to designate the work's subject matter"; and "to play the work". He improves upon Grivel's definition of the title as "a set of linguistic signs ... that may appear at the head of a text to designate it, to indicate its subject matter as a whole, and to entice the targeted public." It is not necessarily that these three functions are met at the same time (76).

From a lexical perspective, to reform is "to improve a system, an organization, a law, etc. by making changes to it"; and reformation means "the act of improving or changing somebody/something." The Reformation refers to "new ideas in religion in $16^{\text {th }}$ century Europe that led to attempts to reform the Roman Catholic Church and to forming of the Protestant Churches" (Oxford, 1067-1068). Based on these definitions, it is reasonably clear that the $Q A R T$ translators are seemingly attempting to bring to mind the experience of Martin Luther King who made several radical changes to Christianity. They even argue that the refusal by Palgrave/Macmillan to publish their translation is akin to the stance of a medieval publishing house when it refused to publish Luther's 95 Theses after consulting a very well-established Catholic Bishop. Out of this imitation, they give their translation the title Quran: A Reformist Translation. This title signals undoubtedly that the original text receives several alterations and amendments. Moreover, via the selected title, a great deal of emphasis is placed on the concept of reformation as adopted by the translators. 
By introducing the word "Reformist" in the title, the $Q A R T$ translators allude that the original text will receive several alterations and amendments. This indicates that their translation is neither faithful to the source text nor accurate enough to rest upon to understand the qur'anic text. Readers of this word can infer that the translators are going to introduce new ideas and concepts different from those already agreed upon among Muslim scholars based on the qur'anic discourse. The translated title is the first intervention on part of the translators in the qur'anic text where it shows clearly that the original text will not be faithfully reproduced. It also supports, to the greatest extent, innumerable choices made by the translators over the process of translation.

As far as the title is concerned, the $Q A R T$ translators are concerned with highlighting a specific view by illustrating the way of defining the crucial function of this work. By using the indefinite article "A" before the adjective "Reformist", the translators are surely illustrating that their translation paves the way for other translators adopting similar approaches to translate the meanings of the Glorious Qur'an. Consequently, there are translations made recently which adopt similar approaches to some extent. For example, The Qur'an: A Complete Revelation by Sam Gerrans, published in 2016, and the translation entitled The Great Qur'an: An English Translation by The Monotheist Group, published in 2018.

Yuksel et al. seek to simulate the model originated in Christianity by Martin Luther King in the $16^{\text {th }}$ century. They choose this title out of their view that Islam needs a Luther-like reform. The translators consider their translation an update of the original text. In other words, they consider themselves mediators between past and present having a great deal of freedom in rendering this canonical religious text closer to certain present audiences and seeking to persuade them that almost all interpretations of the Qur'an in the past received a great amount of distortions and misunderstanding for religious, social or political purposes and hence must be thrown away. Hence, they call upon their audiences to cast off all traditional translations and interpretations of the Qur'an and depend on their translation only being the most modern and latest one.

Similarly, the display in which the title is embedded also reflects the main intention of the $Q A R T$ translators. Through the QARTs cover page design, the translators seek to tell their target readers that due to the traditional interpretations and translations of the Qur'an, the human-mind is plunged into pitch darkness. Given this, the only source of light, in their opinion, lies in their reformist paradigm 
or translation, which ignores all backward Islamic sources and relies upon their "reformist" rereading of the Qur'an.

This assumption is supported by the design of the cover page. There is a striking combination of colors to attract attention of the target readers. On a blue background, the word "Quran" is written in a very big font and given the yellow color in the upper part of the page. In the lower part, there is a diagram with a circle in its center colored yellow as well. There are several squares and other shapes around the yellow-colored circle. All these shapes are empty except only one column which is colored yellow and goes straight to the circle. It seems that the diagram in the lower part of the cover page refers to human-mind.

Perceiving the cover page together with the title, the researcher can infer that the image is a clear embodiment and reflection of the QART translators' main intention expressed subsequently via linguistic elements. The yellow color of the word "Quran" and the arrow directed straight to the circle, which is colored yellow as well, can be understood as a symbol for light. The translators seemingly attempt to tell their readers that the only source of light to the human-mind is represented in the QART reading of the Qur'an. They may use the empty squares and shapes around the circle as a reference to all other sources of Islam considering them fruitless materials.

Additionally, the publisher's name is written in yellow as well. The researcher can assume that the publisher name- Brainbow Press- is given the yellow color to communicate to the target readers that this publishing house represents liberty and enlightenment. This assumption is highly supported by the fact that Brainbow Press is the publisher of the translation entitled The Great Qur'an: An English Translation by The Monotheist Group as well as several works by the QART translators.

Moreover, the English word "reform" and its derivatives are widely incorporated into the title page of other works by the QART translators, for example, Manifesto of Islamic Reform. The fact that such a word is used widely, whether at the head of works or as main themes incorporated into the text itself, makes it undoubtedly clear that it is not just a translation on the very meaning and effect of this word but an attempt to provide a project of thinking rather than just a reasonable rendition of the qur'anic text.

\subsection{Preface or Prefatory Introduction}

Preface is the most important element of paratexts. Its importance is derived from the fact that sometimes it is used as a synonym for paratext. Genette uses the 
word "preface to designate every type of introductory (preludial or postludial) text consisting of a discourse produced on the subject of the text that follows or precedes it." Alongside other paratextual elements, "prefaces" play a crucial role in guiding potential audience towards understanding the ways, nature of addresses and purposes for which certain books are selectively translated (161).

Along with guidance and presentation of information, preface enhances the work's value which is usually measured by "its usefulness and its subject matter." It also determines the "choice of a public", which includes not only the particular kind of readers targeted to reach by the authors but also the readers they want to avoid (Genette, 212). Munday assures the importance of translators' preface as a "source of extensive information on the translation approach adopted" in the work in question, proposing that the function of prefaces, particularly in current publications, is to "justify the production of a new translation of a classic work" (32).

In the $Q A R T$, Yuksel et al. provide a long introduction including detailed information about the translators, their work, circumstances of publication, and their approach in translation. It offers additional details that distinguish their translation from other translations of the Qur'an, positioning themselves as part of those people who call for Islamic reform and other translators as part of the blindmind traditionalists.

The $Q A R T$ translators use their preface to create a certain frame space. They try to position themselves and all other translators of the Qur'an in the reformist/traditional interface. This classification depicts other translators of the Qur'an, whether Muslims or non-Muslims as well as those from various cultural, linguistic, and even religious backgrounds, as traditional translators who deal with the Qur'an as a static text by blindly relying upon the traditional sources of Islam. Thus, the $Q A R T$ is positioned alongside all previous translations of the Qur'an in the same religious, cultural, social and political space. This positioning is also evident in the comparisons made by the $Q A R T$ translators in their preface/introduction between their translation and those made by Pikthall, Yusuf Ali and Shakir.

Furthermore, the issues selected by Yuksel et al. to discuss throughout their preface/introduction play a crucial role in describing a narrative in which they and other people involved in the discussed issues, such as feminist activists, are positioned together, on one side. The opposite side, in their view, includes those who hold traditional concepts relating to the discussed issues. The QART translators consider all people sharing with them similar concerns and thoughts as the new 
invitations for reformation. At the same time, they see those who hold antagonistic thoughts and beliefs as typical voices of the blind traditional thoughts and intellectual.

The preface/introduction presented by Yuksel et al. prepares the scene for perceiving every part in their translation from this positioning viewpoint. It also motivates the target readers to understand each part of the translation as evidence of logicality and rationality of the $Q A R T$ approach. In so doing, the translators promote their scheme, designed to challenge and refute all other opposite models, by undermining others' approach and, at the same time, promoting and strengthening theirs. Here, the $Q A R T$ translators' preface/introduction is used to undermine possible criticism for exceeding the borders of their frame space as translators. Hence, they clarify some reasons for their intervention.

The circumstances surrounding the work of translation fall among what Genette calls "factual paratext" elements, which refers to or modify its importance even though they are implicit. Notwithstanding, the $Q A R T$ translators explicitly state in their preface that they have faced numerous challenges during their journey to publish their translation and bring it to light. One form of these challenges is represented in the refusal of Palgrave/Macmillan to publish the $Q A R T$. Yuksel states:

In 2004, my colleagues and I signed a contract with Palgrave/Macmillan publishing house for the publication of Quran: A Reformist Translation. The editor and other staff of the publishing house were very encouraging and enthusiastic, and during the summer of 2006, I was personally introduced to the director of the publishing company at its New York headquarters. Palgrave even published an announcement about the upcoming Reformist Translation in their 2006 Fall/Winter Catalogue, which was later postponed to the summer of 2007. The publishing house posted information about the Reformist Translation for pre-orders at Amazon.com and other online bookstores. However, in December 2006, the editor informed me that the board had determined that my manuscript was not acceptable for publication.

Apparently, they were convinced or intimidated by a review (more accurately, a fatwa) of "a very well-established professor," who misleadingly likened our annotated translation of the Quran to Salman Rushdie's Satanic Verses. ... (10) 
It is not necessary to bring such facts to the potential readers' attention. However, the QART translators mention such an event to encourage a bigger number of people to read the translation in order to discover the reasons which led to rejection of publication. Apparently, they make such facts explicit for purposes of promotion of their translated version of the Qur'an. In their view, shedding some light on the controversies surrounding their translation inevitably motivates a very big number of people to take a close look into this translation.

In the QART preface/introduction, the reasons given by Yuksel et al. for making a new translation were that almost all previous translations of the Qur'an have included numerous mistakes and distortions due to the too-heavy reliance on the traditional sources of Islam other than the Qur'an. Hence, there is a need to correct such mistakes and distortions in the translation. They openly acknowledge that they correct some concepts and ideas allegedly misinterpreted by other translators.

The $Q A R T$ translators give their introduction the title "translators' introduction: The Case for Reformist Translation of the Quran." This introduction provides an outline of the perspectives held by the translators towards the qur'anic text. It tells many things about the way those translators want their target readers to see the Qur'an. It is pregnant with numerous concepts and information to the extent that an independent study may be undertaken on this introduction alone.

The translators begin their preface/introduction with assuring that their work is carried out in contradiction to the "practices and teachings of Orthodox Islam" which have caused several controversies." This statement gives the impression that their translation is a revolution against all classic sources of Islam. Then, they determine three main objectives:

Quran: A Reformist Translation is an English version of the Quran that takes an accurate reading of what is in the Quran itself as the standard. It thus abandons the rigid preconceptions of all-male scholarly and political hierarchies that gave rise to the series of writings and teachings known as the "Hadith \& Sunna", which, according to the Quran itself, carry no authority... It is a progressive translation of the final revelation of God to all of humanity - a translation that resonates powerfully with contemporary notions of gender equality, progressivism, and intellectual independence... It is a continuation of the modern monotheist movement. (12) 
They allege that interpretation of the Qur'an has been heavily influenced by cultural custom and practices of the Arabs and such practices "were attributed to Prophet Muhammed and his close friends, and introduced as secondary religious sources besides the Quran." They add, "When translation is liberated from these traditions, the Quran conveys a clear message that proclaims freedom of faith, promotes male and female equality, and encourages critical thought and the pursuit of knowledge" (13). These statements indicate that their translation reflects several differences from other ones. Along the same lines, the translators call for noncompliance with any rules or norms while rendering the qur'anic text. They try to conceptualize the Qur'an as a text accessible by all people irrespective of their religion or purposes. Here, the translators seek to enhance the frame of 'reformist approach of translation' versus 'traditional orthodox approach of translation'.

Yuksel et al. argue as well that their translation provides a "peaceful and unifying message of the Quran" to "increase understanding and reduce tensions between the 'Muslim world' and people of other religions." They also illustrate that their translation sheds some light on the major differences between their approach and that "of orthodox translations and commentaries" (13). Here, the translators direct their target readers to expect several subjective interferences into the original text, particularly the qur'anic verses concerned with the relationship between Muslims and followers of other religions. One can infer that the translators try to adapt their translation in this regard to the modern views on religious issues such as plurality or philosophy of perennialism. By stating that the $Q A R T$ is "peaceful", the translators hint strongly that other translations are not peaceful; consequently, they make great efforts to shape the frame of peaceful translation against unpeaceful translations.

The QART translators consider the Glorious Qur'an a text interpretable by all people regardless of their religions or religious backgrounds. This is obvious in their statement that they adopt "an inclusive approach incorporating input from scholars, lay readers, and even non-Muslims" in order to correct the "egregious historical biases so obvious in previous English translations" (13). By stating that their translation "offers a non-sexist" understanding of the Qur'an, the translators establish that their translation takes into account some issues of women whom, in their views, have been suppressed over history. This statement implies that other translations of the Glorious Qur'an are sexist and hence supports the 'sexist' versus 'anti-sexist frame'. 
Finally, the $Q A R T$ preface/introduction reveals that the translators insist on being significantly visible and suppress any reference to any source in Islam other than the Qur'an. They show a strong rejection of any reliance on any classical religious texts whatsoever. Nevertheless, they suggest that Muslims may benefit from such sources not as religious references but as historical ones. They place a great deal of emphasis on several gender issues from a radical feminist point of view. They suggest that any "modern commentary on the Quran...should reflect the perspective and critical evaluation of diverse disciplines and populations" (13).

\subsection{Intertitles}

Generally speaking, intertitles are the internal titles which "appear within books: titles of parts, chapters, sections, and so forth." They are very important particularly in literary works such as plays, novels, collections of poems or short stories. They may be "obligatory" in some works due to their role in identifying the point at which a new chapter begins (Genette, 103). Their most important function, according to Genette, is to divide long texts into meaningful separated parts for purpose of reading convenience. In other words, intertitles punctuate any text into meaningful units via giving numbers, titled chapters, numbered sections or just blank spaces (294).

The Glorious Qur'an fall among the texts where there is no need to intertitles. It is already well organized into parts, chapters (suras), sections, and verses for convenience of readers and interpretations. Nevertheless, the QART translators use several intertitles throughout all the qur'anic text to construct some new frames or manipulate some existing conceptualizations about certain social, political, and religious issues. They frame them in certain ways to realize essential changes in the qur'anic text. To put it another way, they create several secondary frames to support their main frame sought throughout this translation; that is, 'reformist translation' versus 'traditional orthodox translations' or 'reformist paradigm' versus 'traditional orthodox paradigm. They create new frames relying upon the intertitles through a number of techniques such as "labelling".

In the $Q A R T$, there are several applications of the strategy of "labelling" in order to (re)frame certain narratives through the paratextual elements. For example, the translators use a number of intertitles to place a great deal of stress on certain parts to designate specific frames coping with their intended paradigm of the Qur'an. They exploit the strategy of "labelling", via the intertitles, among other strategies, for instance, to reassure the (re)frame of 'monotheist' versus 'polytheist' or 'modern monotheist(s)' versus 'modern polytheist(s)'. Through their intrusion, 
they portray two categories of people by concentrating on the translators' own perception rather than the intended meaning of the original text. They use these two terms as a vehicle of manipulation to alter essential concepts in the Qur'an. Here, the strategy of "labelling" is used in conjunction with the technique of "repositioning of the participants".

In the $Q A R T$, the translators use the label 'monotheist(s)' to refer to themselves and those who share with them the same reformist beliefs. At the same time, they use the label 'polytheist(s)' to refer to those who reject their reformist beliefs and follow other sources of Islam in addition to the Glorious Qur'an to understand essentials and rulings of Islam. In other words, they position themselves together with those adopting similar beliefs on one side and on the other opposite side those opposing their beliefs.

When referring to themselves and those adopting the same reformist beliefs, they use a positive labelling making all choices that present themselves and followers of their beliefs in a very positive light. They enhance this frame by applying several narratives in the Qur'an to themselves. For instance, they use the إن اله اشترى من الهؤمنين أنفسهم وأموالهم بأن لهم الجنة waPamwâlahum bi?anna lahumu-ljannah/ within the translated text. Through this intertitle, Yuksel et al. put themselves in the position of those companions from Madinah who entered into a pledge with Prophet Muhammad at the beginning of Islam and invited him to relocate to their city. The translators want to say that their conflict with all Muslim scholars (called mushriks in the QART) and traditional sources is akin to the conflict between Prophet Muhammad and his followers on one side, and all those against him and his companions on the opposite side. They want to make it clear that their pledge to reject all Islamic sources other than the Qur'an alone is similar to the pledge by the Prophet's companions to reject all religions and gods other than Islam and Allah alone.

The QART translators use the intertitle "Monotheists are Fearless" before the qur'anic verse 3:173 إنذين قال لهم الناس إن الناس قد جعوا لكم فاخشوهم /Rallaðîna qâla lahumu-nnâsu Pinna-nnâsa qad jama̧û lakum faxšawhum/. Together with the two preceding verses, this verse includes warnings for the people of Madinah against any overall attack by the people of Makkah. This is because after the battle of Uhud, the Makkan polytheists assembled to destroy the force of Prophet Muhammad and his companions. They even sent an agent to Madinah to spread the news that Quraysh had made great plans for war and tried to have a huge army that 
would be strong that no force in Arabia could stop or resist it (Abdu, Vol. 4:237239; Ibn Ashur, Vol. 4:168; and Mawdudi, Vol. 1:300). Allegorically, it means those who submit themselves cheerfully to God at any time should not fear from any warnings or threats from any enemies to their religion. Likewise, the $Q A R T$ translators and their followers do not fear from any potential threats or warnings from any traditional Muslims (called mushriks in the $Q A R T$ ) against them as promotors of a new reformist paradigm of Islam.

Then, Yuksel et al. use the intertitle "Monotheism: The Right Paradigm" before the qur'anic verse 2:135 وقالوا كونوا هوداً أو نصارى تهتدوا قل بل ملة إبر/هيم حنبفاً /waqâlû kûnû hûdan Paw nasârâ tahtadû qul bal millata Pibrâhîma hanîfan / to propagate their suggested paradigm of Islam. The context of this verse assures that guidance is achieved by following the creed of Ibrahim, which has been ratified and confirmed by Islam. The $Q A R T$ translators argue that there is a close connection between their model and Prophet Ibrahim's one. They heavily show that he was the only true believer at his time as the case with them where they, and other similar reformists who adopt their paradigm of reformation, are the only modern true believers. Thus, their formula of reformation is the "right paradigm" which must be followed by all Muslims and recognized by even non-Muslim people.

They resemble their paradigm to Prophet Ibrahim's model because he is described in the Qur'an as حنبفاً / خanifan/ which means, according to Dictionary of Qur'anic Usage (239), "inclined towards [God], inclined away [from false deities] and so considered upright." In addition, it is used to "describe ascetic monotheists of Mecca who refused idolatry and its practices." Consequently, in their views, the reformists refuse the idolatry innovated by traditional Muslims by tending themselves to God alone like Prophet Ibrahim when he refused the idolatry of his people and inclined to God alone. This argument is supported by the QART intertitle "Abraham, the Model Monotheist and Re-former" before the qur'anic verse

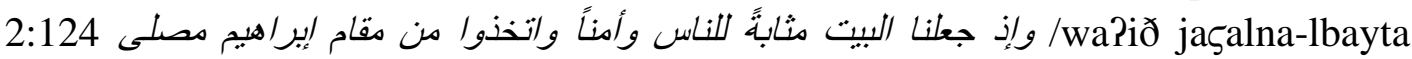
maقâbata-linnâsi wa?amna-wattaxiðû mim-maqâmi Pibrâhîma mu'sallâ/ as well.

In consistency with this and through the strategy of 'intertitles', the $Q A R T$ translators put further emphasis on other positive features to give their approach more strength. For instance, they introduce the intertitle "Monotheists Side With the

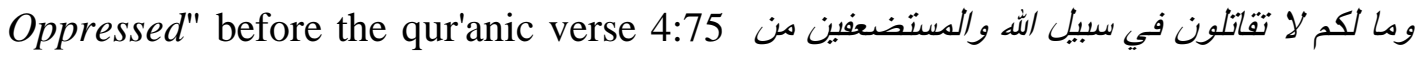
(wamâ lakum lâ tuqâtilûna fi-sabîli-llâhi walmustad_cafîna minarrijâli wannisâ?i walwildân/ in the QART. This verse, according to books of exegesis and commentaries such as al-Manar (Vol. 5:259), al-Tahrir wa al-Tanwir 
(Vol. 5:122-123), Tafhim al-Qur'an (Vol. 2:59), refers to the oppressed men, women, and children in Makkah because they were mistreated and prevented from migrating to Madinah in order to protect themselves from the persecution of disbelievers. Thus, Allah urges Muslims to fight in order to help and liberate the oppressed and suffering Muslims. In their view, as monotheists, the QART translators argue that they are ordered, by virtue of this verse, to help the modern oppressed people, particularly women, to get rid of the oppression imposed on them by the 'patriarchal traditional sources of Islam' and Muslims. To put it simply, they seek to assure that Allah ordains them, as the 'modern monotheists', to incline towards the oppressed persons currently.

Pushing forward with their created 'monotheists versus polytheists' or 'modern monotheist(s)' versus 'modern polytheist(s)' frame, Yuksel et al. use the intertitle "The Brave Monotheist and the Prophecy" before the qur'anic verse 40:28

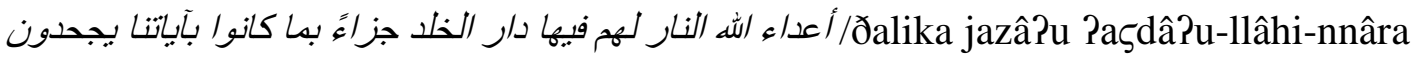
lahum fîhâ dâru-lxuldi jazâ?am-bimâ kânû biجâyâtinâ yajhadûn/. Together with the preceding and following verses, verse 40:28 refers, according to exegetes and commentators such as Ibn Kathir (Vol. 8:476), Ibn Ashur (Vol. 24:127-129), and Nasr et al. (2107) to the story of the believing man from the people of /fircawn/ 'Pharaoh'. This believing man bravely objected to Pharaoh's determination to kill Prophet Moses موسى/mûsâ/ and hence endangered his life by challenging Pharaoh's intention. Similarly, the $Q A R T$ translators put themselves in place of the believing man mentioned in these verses but all people opposing their approach in place of Pharaoh and his supporters and affiliates. This is apparently obvious in their comment on the above qur'anic verse 40:28, where they state, "Unappreciative people, who will try to cover the clear prophecies, will resort to Pharaoh's statement" (395). Thus, they consider themselves the modern 'brave monotheists' and believers but all people against their beliefs the modern 'polytheists' and disbelievers. In their view, they put their life, freedom and safety in danger by fighting for justice, truth and rights of others exactly as the believing man in Pharaoh's people did.

Yuksel et al. keep faith with their approach arguing, "God is Supporting the Monotheists". They put this intertitle before the qur'anic verse 9:117 لقد تاب الله على llaqad tâba-llâhu ऽala-nnabiyyi walmuhâjirîna walPansâri-llaðîna-ttaba̧ûhu fi-sâcati-ļ̧usrati/ which, according to Tafsir Ibn Kathir (Vol. 3:327-328), Tafhim al-Qur'an (Vol. 2:221-222), and The Study Quran (653), means Allah pardoned Prophet Muhammad and his companions. For instance, in Tafhim al-Qur'an (Vol. 3:264), it is explained that the 
Prophet's lapse "consisted of granting exemption to those who had sought his permission although they were fully able to make jihad." The companions' mistake was represented in their "initial reluctance and fear" to accompany the Prophet in his wars. In their own view, the $Q A R T$ translators establish that Allah will pardon them as the 'modern monotheists' exactly the same way He pardoned their ancestors of ancient 'monotheists' because monotheists are often supported and advocated by God.

On the other side of the coin, Yuksel et al. use 'intertitles' as a technique to put their opponents of Muslims into a negative frame using the label 'modern polytheists' to refer to all Muslims opposing their suggested approach of reformation. They attribute to their opponents of Muslims several negative features of wrongdoers and evil people who rejected the divine messages and religions revealed by Allah to His Prophets, as mentioned in the Qur'an. In so doing, they put their opponents in place of those people whom the Qur'an criticized and assured that a violent retribution will be followed against them on the Day of Resurrection.

By way of illustration, the researcher presents some 'intertitles' which strengthen the second part of the frame 'monotheists versus polytheists' or 'modern monotheists versus modern polytheists' constructed in the $Q A R T$. A good example is the intertitle "Polytheists Deny Their Polytheism" placed before the qur'anic

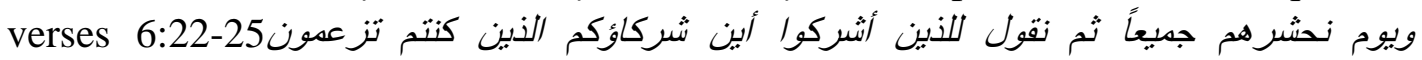

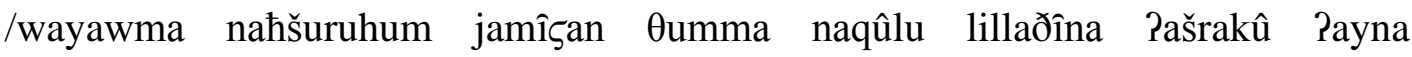
šurakâPukumu-llaðîna kuntum taz̧umûn/. These verses, according to the books of exegesis and commentaries such as Tafsir Ibn Kathir (Vol. 3:327) and The Study Quran (653) depict the questions asked on the Day of Judgment about the false idols worshiped and served by the polytheists instead of Allah. The polytheists however will deny their polytheism and hence the Qur'an calls them liars.

Notwithstanding, the $Q A R T$ translators manipulatively confine the context in these verses to a certain group of people. They apply it to all Muslims who reject their approach of reformation. Through the selected intertitle and their comment on these verses, they present a definition for the word "Polytheists". In their opinion, those "who associate manmade religious teachings and the opinions of their religious scholars with God's word and judgment are mushriks (polytheists), and yet they deny their shirk (polytheism)." They add, "The followers of hadith and sunna are implied by this verse" (175). The QART translators strive to assure that followers of Prophet's Sunnah are among polytheists although they do not know this fact. 
Another manifestation of the present frame which coincides with the $Q A R T$ translators' concept of the label 'polytheists' is found in the intertitle "Polytheists are Disturbed when God is Mentioned Alone". They put this intertitle before the qur'anic verse 39:43 أم /تخذوا من دون الهه شفعاء/Pami-ttaxaðû min-dûni-llâhi šufacâ?/. According to the books of exegesis and commentaries such as Tafsir Ibn Kathir (Vol. 8:397-398), al-Tahrir wa al-Tanwir (Vol. 24:26-30), Tafsir Anwarul Bayan (Vol. 4:420-422) and The Study Quran (2076-2077), this verse, together with the two following ones, condemns the idolaters for worshiping idols and taking them as intercessors besides Allah.

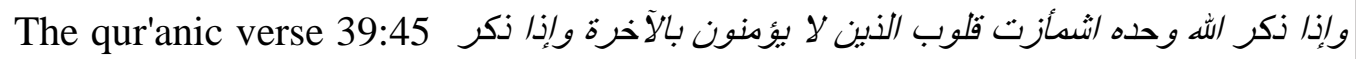
الذين من دونه إذا هم بيتبشرون /waPiðâ ðukira-llâhu wahdahu-šmaPazzat qulûbu-llaðîna lâ yu?minûna bil?âxirah wa?iðâ ðukira-llađîna min dûnihî ?iðâhum yastabširûn/ assures that hearts of the idolaters and unbelievers shudder and become filled with disgust when Allah alone is mentioned but when their idols are mentioned, they rejoice and become happy. They feel discomfort and inconvenient because the names of their idols are not mentioned with the name of Allah. Thus, the verses clarify the polytheists' devotion towards their idols and the depth of their hatred of Islam.

The QART translators use the above intertitle in a different way. Out of their belief that no one other than Allah is granted the powers of intercession, the translators change the topic of these verses. They allege that these verses are connected to Muslims exclusively due to their belief in Prophet Muhammad's intercession on the Day of Judgment. Yuksel et al. further argue that the term 'polytheist' in these verses refers to Muslims because they mention Prophet Muhammad's name with God's name, for instance, in the Arabic expression (الهه محد رسول الشه) /lâ Pilâha Pilla-llâh muhammadun-rasûlu-llâh/. Therefore, in their comment on these verses, the QART translators argue that the "majority of the socalled Muslims... insist on adding Muhammad's name." They even contend that those "who are not happy with uttering God's name alone, those who enjoy adding names of Muhammed... do not really acknowledge the hereafter" (390). The readers of the above intertitle together with these comments will comprehend that Muslims are the polytheists and disbelievers of the Day of Judgment.

In the same vein, the QART translators use the intertitle "Polytheists do not وما قدروا الله حق قدره 39:67 /wamâ qadaru-1lâha haqqa qadrhi/. Together with the preceding verses, the present verse contains other negative characteristics of the 'polytheists' of قريش /qurayš/ in 
particular and 'polytheists' over the history of Islam in general. This verse assures that the worshipers of idols did not appreciate the true majesty and exaltedness of God. They "did not give Allah His due when they worshiped others alongside Him. He is the Almighty... the One Who is able to do all things" (Ibn Kathir, Vol. 8:417). However, in the $Q A R T$, all these negative characteristics and descriptions are attributed to the followers of Prophet's Sunnah accusing them of setting up Prophet Muhammad as a partner with God. Across the qur'anic discourse, Yuksel et al. replace the unbelievers or polytheists with those Muslims believing in Prophet's Sunnah as the second source of Islam.

To put a greater deal of emphasis on the frame 'modern monotheists' versus 'modern polytheists', Yuksel et al. argue that even Prophet Muhammad was not a monotheist before accepting the Qur'an alone. They put the intertitle "Before Receiving the Quran, Muhammed was a Polytheist" before the qur'anic verse 40:66 nul Pinnî nuhîtu Pan Pacbuda-llađîna taḑûna min dûni-llâhi lammâ jâ?anya-lbayynâtu mirrabbî/. The QART translators allege that Prophet Muhammad became a monotheist only when he received the Qur'an. Paradoxically, according to the translators, when his companions and followers complied with his sayings and teachings as reliable material to comprehend the religion of Islam, they became polytheists.

Yuksel et al. use the technique of intertitle as a paratextual element to promote other frames as well. For example, they put the intertitle "Hadith: Satanic وكذلك جعانا لكل نبي عدواً شياطين الإنس والجن 6anspiration" before the qur'anic verse 6:112 wakaðalika jacalnâ likulli nabiyyin ૬aduwwan

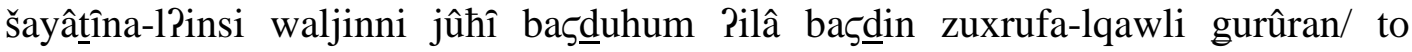
construct the 'satanic inspiration' versus 'God inspiration' frame. To them, Prophet's / \âdî日/ (Sunnah) are just sayings and teachings which have been inspired by Satan and Jews to the blind followers and narrators. Then, those narrators and 'fabricators' attribute those false sayings and teachings to Muhammad. By attributing such sayings and teachings falsely to Muhammad, those narrators and 'fabricators' are the true enemies of him.

This argumentation is glaringly obvious in their footnote annotated to this qur'anic verse as they state, "Comparing the hearsay stories in Hadith books with the percepts in the Quran, we can see why and how their narrators and collectors were indeed the enemies of Muhammad." They add, "None who acknowledges the reality of life after death would be attracted to the fancy words presented as divine inspiration or revelation" (175). Accordingly, the QART translators consider anyone 
believing in Prophet's حديث/hâdî日/ (Sunnah) as the second original source of Islam to be a polytheist, enemy of Prophet Muhammad, and denier of the Day of Judgment. This is because, in their view, only blind disbelievers are attracted to such 'satanic hearsay' and 'fabrications'.

Nevertheless, in the qur'anic verse 6:112, Allah informs Prophet Muhammad that every prophet faced the same challenges and circumstances from the devils in each nation. According to Mawdudi, in this verse, the Prophet is told that "he should not be unnerved even if the evil ones among both mankind and the jinn stood united against him and opposed him with all their might. For this was not the first time that such a thing had happened. Whenever a Prophet came and tried to lead people to the Truth, all the satanic forces joined hands to defeat his mission" (Vol. 2:265-266).

According to the QART interpretation of the Arabic phrase زخرف القول غرورً /zuxrufa-lqawli gurûran/, translated as "fancy words in order to deceive" and the new innovated frame, this phrase refers to the 'false satanic fabricated narrations and hearsay' innovated by the 'so called narrators' and 'fabricators' to mislead people. Contrary to the $Q A R T$ interpretation, this Arabic phrase, according to Mawdudi, refers to:

all the trickery and maneuvering to which the enemy resorts, all his efforts aimed at showing doubts about Islam and undermining people's faith in it, so as to arouse them against both the Prophet... and his message. Taken as a whole, these are characterized as 'delusion' for the weapons used... by the opponents of the Truth have the effect of deluding others as well as themselves. (Vol. 2:266)

Based on the above intertitles employed in the $Q A R T$, it can be said that the translators exploit the labeling technique to deviate from the frames already created in minds of the source-text readers. Through framing by labelling, their choices signal different narratives than those of the ST; thus, leading the target readers to a certain image of the qur'anic text. Furthermore, through the above-cited intertitles, the $Q A R T$ translators reposition themselves and other people in the real world. They divide the whole world into two groups: one group includes all people who accept their beliefs and views, regardless of their religion; the other group includes all people opposing the $Q A R T$ version. They position all people agreeing with their paradigm of Islam on the side of prophets and monotheists, on one hand. On the 
other hand, they position all people opposing their views alongside polytheists and opponents of all prophets in the same religious space.

\subsection{Notes/Endnotes}

Generally, as a paratextual tool, "a note is a statement of variable length (one word is enough) connected to a more or less definite segment of text and either placed opposite or keyed to this segment" (Genette, 319). As a translation strategy, translator's notes are paratextual elements in which "the translator makes his or her voice heard, thus giving us his or her invisible position in order to address the reader directly. Together with other paratextual components, translators' notes accompany the text and influence how it is read and interpreted. Translators usually resort to using notes in different times and due to different intentions. Notes are usually found "printed at the bottom of the page or in its margins", but can "also be included at the end of each chapter or book" (Buendia, 149-151).

Buendia adds that notes can act as a commentary and have a 'discursive' or 'performative function'. To put it another way, it infringes the norms of reproducing the source text objectively due to the several unjustifiable intrusions of the translators during the process of translation. This type of notes usually takes "the reader to another order of reality", serves as "a vehicle for the confrontation of other views... within the text itself", and shows that translating often reflects a specific "poetics and that it manipulates the text so that it functions in a given society" (160161). The endnotes employed in the $Q A R T$ are, in most cases, a perfect example of this type.

In the $Q A R T$, the translators put forward that they use "endnotes to alert the reader to orthodox or sectarian distortions." They also state that the "endnotes are an attempt to accommodate some of...differences" between the participants of the $Q A R T$ as "independent thinkers" who have "different backgrounds, education, and experience." Through endnotes, there are as well "some cross-references to the Bible, which shares a common message and numerous events and characters with the Quran" (15). These statements lead the potential readers to discern that the translators are going to apply several forms of correction to the main text through this paratextual element for various purposes.

As a matter of illustration, this article provides some examples of how the endnotes are employed in the $Q A R T$ to clarify, for instance: how the $Q A R T$ translators use endnotes to wage a war on the methodology of other translations of the Qur'an and highlight the strengths of theirs; how they allege that almost all other 
translations of the Qur'an contain several misinterpretations and distortions; and how their translation stands as a rectification of such errors and mistakes. In other words, the article tries to illustrate how the $Q A R T$ translators position their product and other translations of the Qur'an; their views and others' views; themselves and other translators or commentators of the Qur'an; as well as repositioning other participants in the original text.

As mentioned above, a perfect example of application of the endnotes functioned in the QART lies in the translators' comment on the qur'anic verse عسى ربه إن طلقكن أن بيدله أزواجاً خبراً منكن مسلماتٍ مؤمناتٍ قانتاتٍ عابداتٍ سائحاتٍ ثيبات وأبكارًا /కsâ rabbuhû Pin tallaqakunna Pan yubdilahû Pzwâjan xayram minkunna

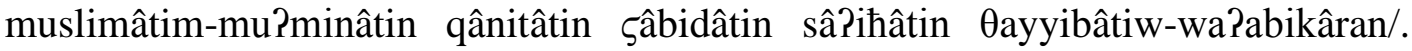
Under this endnote, they criticize other translations and commentaries of the Qur'an and seek to reinforce a certain reading of the qur'anic text. They reject those translations calling them 'traditional orthodox translations of the Qur'an'. In the present example, the $Q A R T$ translators argue, "Traditional translations mistranslate the last three adjectives used here to describe Muslim women" (464).

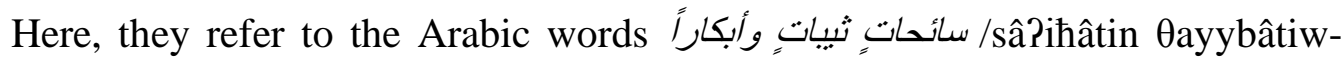
waPabkâran/. They render the Arabic word سائحات / sâ?ihâtin/ as "active in their societies" although it means "those who travel about, as for reasons of faith, those who fast as a way of purifying themselves, the devout" (Dictionary of 471) or "emigrants" (al-Tahrir wa, Vol. 28:361). This Arabic word سائحاتٍ sâ?iћâtin/ comprises several religious implications such as: travelling from a place to another for sake of Allah to perform certain religious rituals such as pilgrimage; emigrating to Allah spiritually by staying alone in some place to remind Allah and perform prayers; or fasting several days other than the obligatory fasting during the month of Ramadan for purposes of purification in all cases. However, in the endnote to this verse, the $Q A R T$ translators attempt to justify their choice stating that "The misogynistic mind of orthodox commentators and translators simply could not fathom the notion of a Muslim woman traveling around alone to do anything - and so they pretended that the word in question was...fasting." They add that commentators and translators render this Arabic item as "fasters" due to the fact that "Socially active women were indeed more difficult to control than the women who would fast in their homes; they were even less costly, since they would eat less" (465-466).

As for the Arabic words ثياتٍ وأبكارً/Oayybâtin-waPabkâran/, they are rendered in the $Q A R T$ as "responsive, and foremost ones" respectively. Concerning the 
former, the $Q A R T$ translators argue that it refers to "those who return, or those who are responsive." The latter, according to them, means "those who are young, early risers or foremost." In the endnote, they allege that the misinterpretation and distortion of the latter as "virgins" by the traditional translators and commentators have resulted in supporting "a sectarian teaching that justifies a man marrying more than one virgin" (466).

The $Q A R T$ translators use endnotes to create some frames completely different from those found in minds of the source-text readers. A perfect example of employing "endnotes" to create new frames and hence intervene into the qur'anic text by the $Q A R T$ translators lies in their comments on several verses related to women. They seek to make up the 'antisexist translation' versus 'sexist translation' frame. For instance, their commentary endnote annotated to the qur'anic verse 2:222 /وسيسألك نك عن الدحيض قل هو أذيَّ فاعتزلوا النساء في الهحيض huwa Paðan fastazilu-nnisâ?a fi-lmahîdi/. This verse discusses rulings of menstruating women. The translators state that "prohibition of sexual intercourse during mensuration is for the protection of women from pain and potential inflection. Other than that, menstruating women should continue their contact prayers, charity work, fasting, and studying the Qur'an." They add, "Commentaries based on hadith and sunna, not only mistranslate the word tahara, but also fabricate a list of prohibitions for women" during the period of menstruation (96). Here, the translators are concerned with furnishing their views rather than explaining any vague expressions contained in the main text objectively.

Another example of promotion of the above frame is represented in the $Q A R T$

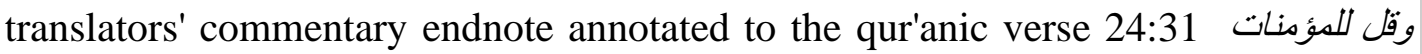
بغضضن من أبصار هن ويحفظن فروجهن ول بيدين زينتهن 'waqul-lilmu?minâti yagdudna min Pabsârihinna wayahfað̄na frûjahunna walâ yubdîna zînatahunna/. This verse discusses, among other things, the injunctions and rules of dressing for women. Yuksel et al., argue, "God uses flexible language, to allow culture, time, climate, age, and social dynamics and other variables to play a role in the decision." They add that the Qur'an does not include anything ordering "government or the society to force women, in the name of God, to cover themselves" and "a punishment neither in this world nor in the hereafter is issued." They go even further and suggest that "It is up to women, not men, how long they will lower their dress, whether they will cover their breasts or not" (318). In so doing, the translators provide new opinions contradictory to the unanimously agreed injunctions inferred from these verses by the majority of Muslim scholars to achieve a certain influence on the main text itself for feminist considerations. 
This leads Yuksel et al. to omit the Arabic jussive verb ولو تبرجن/walâ tabarrajna/ in the qur'anic verse 33:33 ول تبرجن تبرج الجاهلية الأولى /walâ tabarrajna tabarruja-ljâhiliyyahti-lipulâ/ translating this sentence as "do not be about like the olden days of ignorance". The Arabic verb تبرجن/tabarrajn/, referring to women, means "to adorn themselves in an enticing way, in a lust-causing way; to expose themselves in an alluring way." The Arabic word متبرجة/mutabarrijah/means "those who flaunt their bodies in an alluring way, display their adornment enticingly" (Dictionary of 85). This portion of the verse 33:33 includes a general rule that women are prevented from wearing clothes which display their finery when going out of their homes. However, Yuksel et al. conceal this qur'anic prohibition out of their view that there is no such a rule in Islam that governs clothing for women.

To strengthen the above frame via endnotes as well, the $Q A R T$ translators criticize interpretation of the qur'anic verse 78:33 وكواعب أترابًا wakawâciba كatrâban/ by other translators. In this verse, the two Arabic cultural words كواعب / أتراباً /kawâçiba Patrâban/, rendered in the QART as "scrumptious and ripe", mean 'youthful maidens of equal age'. Commenting on this verse, exegetes and commentators of the Qur'an such as Ibn Kathir (Vol.10:333-334), Ibn Ashur (Vol. 10:44), and Nasr et al.(2682) explain that it refers to 'maidens with full breasts'; those who will be fully mature but, at the same time, their bodies will not be subject to the vicissitudes of time. The verse also includes that husbands and wives will be of the same age, as one of the numerous bounties granted to the righteous in the paradise.

However, the $Q A R T$ translators render it differently, explaining in the endnote that this verse "is translated by many male translators as description of women, but in the context, it makes more sense to consider it as the description of the fruits of the vineyards mentioned in the previous verse" (484). Here, the translators drift away from the original meaning to meet their views and hence serve both 'sexist' versus 'non-sexist' and 'reformist translation' versus 'traditional orthodox translations' frames. This argument is clearly evident in their endnote comment on the qur'anic verse 66:5, stating, "The misogynistic mind of orthodox commentators and translators simply could not fathom the notion of a Muslim woman travelling around alone to do anything" (465).

The QART translators exploit endnotes also to reposition some participants in the original text. In other words, they use endnotes to pass on some perspectives relating to several main narratives of the Quranic discourse such as the status of prophets and messengers of God. Against agreement among all Muslim scholars as 
to infallibility of prophets, Yuksel et al. seek assurance that any human being is subject to criticism due to their errors, sins, and mistakes even prophets and messengers of God. In their commentary endnote annotated to the qur'anic verse 49:1 /ليا أيها الذين آمنو/ لا تقدم/ بين بيدي اله ورسوله /yâ Payyuha-llađîna Pâmanû lâ tuqaddimû bayna yadayi-llâhi warasûlihi/, Yuksel et al allege that prophets and messengers "make mistakes. Thus, when believers made a covenant with prophet Muhammed, they promised to obey him conditionally." Additionally, believers are entitled to discuss anything with prophets, object to their opinions and prophets should not ask any one of their followers to do anything without consultation and acceptance (424-425).

In the same way, the translators suggest, "During their lifetimes, messengers are community leaders" whose obedience is not absolute but "is open to consultation and discussion." During their lives, "we have the chance to ask them further questions, discuss issues, learn their intentions, and even correct their mistakes... However, when they pass away, their teaching becomes frozen." Such a frozen teaching is "a dangerous weapon in the hands of ignorant people; they use it to stop God's perpetual teaching." They continue to add, "The belief that God is represented by the Quran, and the messenger by his teaching is a satanic claim" (425).

Furthermore, as messengers and prophets of God are fallible, according to Yuksel et al., they are subject to criticism and hence those people who reject the prophets' message are justifiable. This is glaringly obvious in their commentary وما أرسلنا من قبلك من رسول ول نبي إل إذا تصنى ألقى الشيطان في أمنيته Pillâ Piðâ tamannâ Palqa-ššaytânu fî Pumniyyatihi/. They state, "The weakness and deficiencies demonstrated by messengers and prophets provide excuses for those who try to criticize them and reject their message... those deficiencies and weakness reject the common Sunni and Shiite belief that the messengers are 'innocent' or 'sinless' people" (307).

The $Q A R T$ translators make use of endnotes to portray themselves as 'peaceful reformers (modern monotheists/peacemakers)' while their opponents as 'warmongers (modern polytheists)'. They give themselves and their supporters the same position of prophets and messengers who were aggressed and killed by polytheists because of denying corruption and aggression of their polytheist peoples, on one side. On the opposite side, they portray other translators and 
commentators of the Qur'an and opponents of the alleged reformist version of the Qur'an as aggressors and 'warmongers'. This is plainly evident in their statement:

The Quran informs us that many messengers were killed by mushriks. Mushrik leaders who know well that their doctrine cannot survive the scrutiny of thinking and questioning minds, have always waged war and terror against messengers of God who invited to reason, questioned traditions and superstitions, and promoted peaceful coexistence. It is no coincidence that similar authoritarian, aggressive, warmongering characteristics are also common among modern polytheists, regardless of their religion. (286)

Yuksel et al. use endnotes also to assure that it was Prophet Muhammad who started their 'progressive/reformist movement' by leading a revolution in "theology, philosophy, culture, economy and politics." Like the case with them, he "became the target of defamation campaigns" conspired by his opponents to "eliminate him and his supporters" and hence stop his 'progressive movement' (364-365).

Through the $Q A R T$, the endnotes expose the negative representation of Prophet's Hadiths as perceived by the translators. Due to their own negative perception of Prophet's Hadiths, the translators warn against, in their view, Hadiths' destructive power and the danger they represent to the true interpretation of the ما كان على 33:38

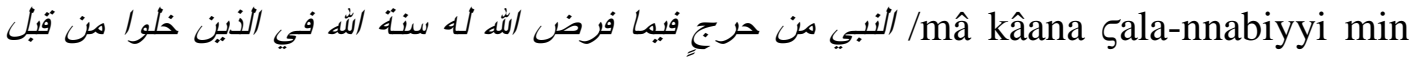
harajin fîmâ farada-llâhu lah sunnata-llâhi fi-llaðîna xalaw min qablu/, they claim, "When the Quran uses the word hadith (word; saying; narration) for something other than itself, it usually uses it in a negative way or context" (365). They strive to portray prophet's Hadith in a very bad way and hence construct a very negative frame in the minds of the target-text readers.

The translators use endnotes as well to create a negative frame of Prophet's companions out of their argumentation that the Arabic words صاحب/ŝâtib/ 'friend'

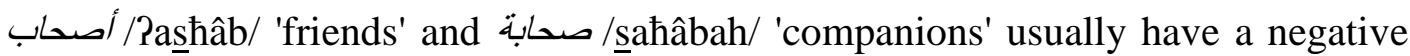
و يقول المنافقون والذبن في قلوبهم مرض ما وعدنا الهه ورسوله إلا غرورً /waPið yaqûlu-lmunâfiqûna wallaðîna fi-qulûbihim maradum-mâ waรadana-llâhu warasûluhu Pilla gurûran/, they argue, "Sunni literature tries to establish a taboo on discussing or criticizing any companion" seeing them as "infallible or saint-like" people. They add, "The Quran, however, gives us a very different picture of Muhammed's companions. The Quran uses the word sahaba and its plural ashab for all companions of Muhammed, 
including his opponents, hypocrites, and Muslims" (363). Yuksel et al. also use the intertitle "Hypocrites among Companions of the Prophet" before this qur'anic verse 33:12 to place a great deal of emphasis on the negative depiction of Prophet's companions. Moreover, in their endnote to the qur'anic verse 53:2, they argue, "The word Saheb, Sahaba, and its plural Ashab are usually used in a negative context... the word 'Ashab' is usually used to denote disbelievers and hypocrites" (434).

In the same vein, the $Q A R T$ translators employ endnotes to demolish some Islamic well-known terms such as the Arabic term سلف/salaf/ 'ancestors'. In their comment on the qur'anic verse 43:56 فجعناهم سلفاً ومثلًا للآخرين/fajaรalnâhum salafanwama日alan-lil?âxirîn/, they argue that this Arabic word is among the "labels and names that are convicted by the Qur'an" adding, "As we noted in relation to the words hadith, sunna, and ijma, the word salaf too has negative connotations in the Quran." They even argue, "it is used as a reference to a community of people who were ignorant, aggressive and oppressive." They come to contend, "The majority of salafis live in Saudi Arabia and they promote a Taliban-style tyrannical system that produces an ignorant, misogynistic and backward crowd who subject themselves to being herded like sheep by the moral police" (409).

Together with the preceding verses, this verse informs Prophet Muhammad of the story of the people of Prophet Moses and how Allah had punished them for their wrongdoings by drowning them all in sea, causing them to recede into history and making them a bygone people, a lesson, and an example for those who come later (Ibn Kathir, Vol. 8:647-648; Ibn Ashur, Vol. 25:235; Emerick, Vol. 3:134; Nasr et al., 2204). However, Yuksel et al. confine it to the followers of an Islamic school of jurisprudence. They put not only those called salafis but also the Saudi people in a negative frame describing them as "backward", "ingnorant", "misogynistic", and "sheep" like.

Yuksel et al. use endnotes as well to revile the narrators and collectors of the authentic books of hadith and demolish Prophet's hadiths labelling them "holy fabrications" and considering this source of Islamic legislation as "a new occupation". For instance, in their commentary endnote annotated to the qur'anic verses 2:67-73 وإذ قال موسى لقومه إن اله يأمركم أن تنبحوا بقرة waPið qâla mûsâ liqawmihi Pinna-llâha ya?murukum ?an taðbahû baqarah/, the translators argue, "Two centuries after Muhammed's departure, some ignorant zealots such as Bukhari, Muslim, Tirmizi, Abu Dawud, Nasai, and Ibn Hanbal started collecting and classifying the stories in numerous hadith books. These volumes of contradictory 'holy fabrications' created a new occupation" (88). 
The QART translators use endnotes also to defame the public image of clergymen considering them as "puppet clerics". They put forth that clergymen "turned God's system into a theo-fiction consisting of superstitions, collections of silly rituals, frivolous rules, absurd doctrines, numerous prohibitions, opium of masses, intellectual slavery and wishful thinking" (163).

Driven by their rejection of the second part of شهادة/Šahâdah/ 'testimony' as a basic condition and pillar of Islam, the translators claim that the Qur'an contains 'testimony' as a sign of hypocrisy, polytheism and lying. Hence, in their

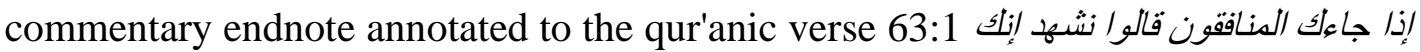
/2iðâ jâ?aka-lmunâfiqûna qâlû našhadu Pinnaka larasûlu-llâhi/, Yuksel et al. claim that this is the only verse in the Qur'an which "contains the second part of the shahada (testimony)" - confession that Muhammad (PBUH) is the messenger of Allah - adding, "God knew in advance that the polytheists would add the name of their idols next to His name. Thus, God mentioned the second part as the utterance of hypocrites." To the QART translators, all Muslims who "add a testimony about Muhammed's messengership in shahada in fact are lying in testimony" (461). They even allege that "those who feel the need for such a testimony are described as hypocrites" (114).

In the same lines, through "endnotes", Yuksel et al. mount a savage attack on other basics of Islam such as intercession considering them "holy viruses". For واتقو ايوماً لا تجزي نفس" عن نفسِ شيئًا

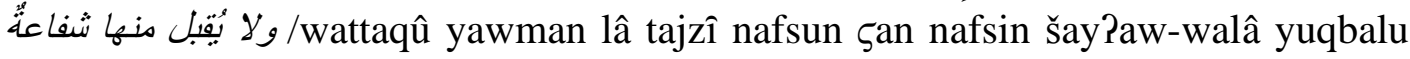
minhâ šafâcatun/, they allege "Belief in intercession is a mythology common in many religions. Satan, via religious clergymen, infected the faith of many people with the virus called intercession. Intercession generates false hope that promotes human-worship" (83). 


\section{Conclusion}

Throughout the above-mentioned paratexts accompanying the selected translation, there are several intrusions from side of the translators. They deliberately manipulated the meaning of the source text negatively and causing several distortions inspired by their views. The translators further abused the convention of use of the paratextual means. In so doing, they sought assertion of their visibility strongly as radical reformist translators who set aside all conservative and traditional readings and exegeses of the meanings of the Glorious Qur'an asserting the necessity to replace all of them by more liberal ones. They have been visible almost in every explanation they provide for each verse and through each paratextual element.

Furthermore, Yuksel et al. made use of paratexts to replace several classic canonical concepts and provisions of Islam by other ones based on their personal conceptualization. This made the $Q A R T$ a more typical work of concepts and views than of faithful transfer of the qur'anic text. As they had expected that their translation would possibly create a state of chaos and controversy, the translators sought out justification of their deviation and choices making their personal interpretation and narration key to the text. Additionally, they made attempts to completely suppress the qur'anic text to express their fully unsubstantiated personal opinions about not only controversial issues but also several essential teachings and pillars of Islam.

In the $Q A R T$, paratexts are filled with several demonstrably incorrect explanations and unfounded or nasty allegations and accusations against whoever disagrees with the translators' proposed approach of thinking and translation. The translators used paratexts widely to promote the concept that all classic sources of Islam have negative impacts and dangers to the extent that they considered such sources as the direct reasons for backwardness and weakness of the Muslim nation. Through the $Q A R T$, an effort has been made to create new sources of Islam and call upon all people, Muslims or non-Muslims, to offer their own contributions, experiences, opinions, and proposals in alignment with the twenty-first century requirements in the translators' view.

It is through paratexts that Yuksel et al. used an insulting language that offends numerous people of the Muslim nation. For instance, they described conservative Muslim scholars as 'puppet clerics'. Performing such a desecration, Yuksel et al. are antagonistic towards not only Prophet's Sunna but to Islam as a whole. Almost all 
readers of this translation will have no problem to fathom that the $Q A R T$ is offensive to any Muslim holding the Prophet's Sunna to be sacred alongside the Glorious Qur'an. Additionally, the translators used paratexts to make unjust war on the collectors and reporters of Prophet's hadiths considering them as 'archenemies of prophet'. They also exploited paratexts as a means to put their words in the mouth of others to savagely attack the Prophet's companions such as Abu Hurayra claiming that Bukhari himself admitted that Omar, Ibn Abbas and Aisha considered Abu Hurayra as 'a congenial liar and fabricator'. The translators as well used paratexts to mount a strong attack on the Muslim caliphs and the kings and emirs of the Muslim countries over history describing them as 'satanic' 'corrupt', 'drunken', 'parrots', 'oppressive', 'hedonistic', etc.

Taking into consideration the translators' statement that their translation is 'antisexist' and hence including a woman in their translation team, the present article has discussed how the translators dealt with the verses pertaining to women. Yuksel et al. exploited paratexts to insert several new rulings and provisions based on a radical feminist perspective such as the right of women to lead prayers, deliver Friday sermons, and reading the Glorious Qur'an and performing prayers during the period of menstruation.

The paper has also shown that the $Q A R T$ translators exploited paratexts to criticize other translations of the Qur'an stridently deeming them among the devices used to defeat women, perpetuate their low status, and bring them under domination and control of men in violation of the real picture in the Qur'an. Through the apparently made comparison between their reformist approach and other 'traditional' approaches of the Qur'an's rendition in their introduction, Yuksel et al. interfered deeply into the original text and fought to secure authentication for their choices. Seeing all such translations patriarchal, Yuksel et al. considered their translation, which, in their view, has reflected the true spirit and massage of the Qur'an, has shown the high position of women by making some radical reforms of the source text.

The translators did not only comment on some information in the original text but also made great efforts to provide keys for the ways of reading and interpreting the target text. They selectively highlighted some considerations enhancing their beliefs and having considerable effects on the way the potential target readers ought to comprehend the qur'anic text. Through paratexts, the translators strived to attribute all positive discourses and characteristics to themselves and those following their reformist paradigm of Islam on one hand. On the other hand, they made efforts to 
elicit a negative image of all those opposing their views. They took every opportunity to frame the qur'anic discourse to their advantage.

The translators exploited paratexts widely to depict negatively not only their opponents but also their viewpoints and attitudes. For instance, they expressed rejection of several concepts of Muslims considering such concepts as 'satanic'. They also desecrated the holiness of numerous rituals in Islam such as pillars of pilgrimage seeing them as 'polytheistic' and 'satanic' rites. The translators launched a bitter attack on some rules related to women for feminist considerations. It is through paratexts that Yuksel et al. waged a severe war against schools of jurisprudence and Muslim scholars considering them 'fabricators'. 


\section{Reading Conventions and Transcription}

The transcription symbols used in this paper follow the IPA conventions with some adaptations for typing convenience. The following is a list of the phonemic symbols used in this study.

\begin{tabular}{|c|c|c|}
\hline $\begin{array}{l}\text { Phonetic } \\
\text { Symbol }\end{array}$ & Description & Examples \\
\hline$/ \mathrm{b} /$ & Voiced bilabial stop. & /bâb/ a door \\
\hline$/ \mathrm{d} /$ & Voiced non-emphatic dental stop. & /dirऽ/ armor \\
\hline$/ \mathrm{t} /$ & Voiceless non-emphatic dental stop. & /tafâ?ul/ optimism \\
\hline$/ \underline{\mathrm{d}} /$ & Voiced emphatic alveolar stop. & / diffah/ a bank \\
\hline$/ \underline{t} /$ & Voiceless emphatic alveolar stop. & / tâPir/ a bird \\
\hline$/ \mathrm{k} /$ & Voiceless velar stop. & /kitâb/a book \\
\hline$/ \mathrm{q} /$ & Voiceless uvular stop. & /qalam/ a pen \\
\hline$/ \mathrm{R} /$ & Voiceless glottal stop. & /Pbyad/white \\
\hline /f/ & Voiceless labio-dental fricative. & /farâšah/ a butterfly \\
\hline$/ / /$ & $\begin{array}{l}\text { Voiced non-emphatic interdental } \\
\text { fricative. }\end{array}$ & /ðirâ̧/ an arm \\
\hline$/ \underline{d} /$ & Voiced emphatic interdental fricative. & /Dalâm/ darkness \\
\hline$/ \theta /$ & Voiceless interdental fricative. & /Oawr/ an ox \\
\hline $\mid z /$ & Voiced alveolar fricative. & /zaytûnah/ an olive \\
\hline$/ \mathrm{s} /$ & $\begin{array}{l}\text { Voiceless non-emphatic alveolar } \\
\text { fricative. }\end{array}$ & /sa̧âdah/ hapiness \\
\hline$/ \underline{s} /$ & Voiceless emphatic alveolar fricative. & /sadâqah/ friendship \\
\hline$/ \check{\mathbf{S}} /$ & Voiceless palato-alveolar fricative. & /šâcir/ a poet \\
\hline$/ \mathrm{x} /$ & Voiceless velar fricative. & /xalîfah/ a caliph \\
\hline$/ g /$ & Voiced uvular fricative. & /gusn/ a branch \\
\hline$|\varsigma|$ & Voiced pharyngeal fricative. & / $\zeta$ aqd/ a contract \\
\hline$/ \mathrm{h} /$ & Voiceless pharyngeal fricative. & /hurriyyah/ freedom \\
\hline$/ \mathrm{h} /$ & Voiceless glottal fricative. & /hilâl/ crescent \\
\hline$/ \mathrm{j} /$ & Voiced palatal affricate. & /jû̌/ hunger \\
\hline$/ \mathrm{m} /$ & Voiced bilabial nasal. & /mir?âh/ a mirror \\
\hline$/ \mathrm{n} /$ & Voiced alveolar nasal. & $\begin{array}{l}\text { /nasîhah/ a piece of } \\
\text { advice }\end{array}$ \\
\hline$/ 1 /$ & Voiced dental lateral. & /laћðah/ a moment \\
\hline$/ \mathrm{r} /$ & Voiced alveolar trill. & /riwâyah/ a novel \\
\hline
\end{tabular}




\begin{tabular}{|c|c|c|}
\hline$/ \mathrm{w} /$ & Voiced bilabial semi-vowel. & /wudûu?/ ablution \\
\hline$/ \mathrm{y} /$ & Voiced palatal semi-vowel. & /yaum/ a day \\
\hline \multicolumn{3}{|c|}{ Vowels } \\
\hline /i/ & High front short unrounded vowel. & /kitâb/ a book \\
\hline$/ \hat{1} /$ & High front long unrounded vowel. & /rabîॅ/ spring \\
\hline /a/ & Low central short vowel. & /qara?a/ he read \\
\hline /â/ & Low central long vowel. & /bâfï/ a researcher \\
\hline$/ \mathrm{u} /$ & High back rounded short vowel. & /qurPân / Quran \\
\hline$/ \mathrm{u} /$ & High back rounded long vowel. & /hût/ a whale \\
\hline
\end{tabular}

\section{Gemination}

Geminated Arabic consonants, i.e. long consonants, are indicated by doubling the phonemic symbols. Doubled consonants are longer and more tense than short consonants, e.g. /murr/ "bitter", /haddada/ "he threatened".

\section{Elision}

Elision here refers to the omission of the voiceless glotal stop / $/$ and the following vowel sound in connected speech. It is indicated by a hyphen. For example, the two words /wazîr/ and / Pattaclîm/ are transcribed, in connected speech, as /wazîru-ttaclîm/"Minister of Education".

\section{Assimilation}

The /1/ sound of the Arabic definite article / $\mathrm{Pal} /$ is assimilated into the initial sound of the noun or adjective to which the article is prefixed. This occurs when $/ \mathrm{Ral} /$ is prefixed to a word beginning with any of the following consonants: /t/, $/ \theta /$,

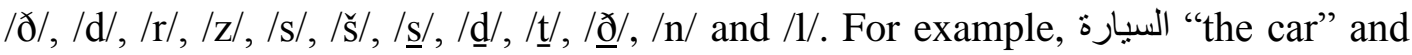
"the soil” are transcribed as /Passayyârah/ and / Patturbah/. 


\section{References}

Abdul-Raof, Hussein. Qur'an Translation: Discourse, Texture and Exegesis. London and New York: Routledge Taylor \& Francis Group, 2001. Print.

Abdu, Muhammad. Tafsir al-Manar. "The Illuminating Exegesis." Vols 12. Cairo: Dar alManar, 1947. Print.

Badawi, Elsaid M. and Muhammad Abdel Haleem, eds. Arabic-English Dictionary of Qur'anic Usage. The Netherlands: Koninklijke Brill NV, 2008. Print.

Baker, Mona. Translation and Conflict: A Narrative Account. London \& New York: Routledge Taylor \& Francis Group, 2006. Print.

Buendia, Carmen Toledano. "Listening to the voice of the translator: A description of translator's notes as paratextual elements." The International Journal for Translation \& Interpreting Research. Vol. 5, No. 2 (2013): 149-162. Print.

Emerick, Yahiya. The Meanings of the holy Qur'an in Today's English. Vols 3. United States of America, CreateSpace Independent Publishing Platform, 2011. Print.

Genette, Gerard. Paratexts: Thresholds of Interpretation. Trans. Jane E. Lewin. Cambridge: Cambridge University Press, 1997. Print.

Hejwowski, Krzysztof. Translation: A Cognitive-Communicative Approach. Oclecko: Wszechnica Mazurska, 2004. Print.

Hassen, Rim. "English Translations of the Quran by Women: Different or Derived?" Diss. U of Warwick, 2012. Print.

Hornby A. S. Oxford Advanced Learner's Dictionary of Current English. $6^{\text {th }}$ ed. Oxford: Oxford University Press, 2004. Print.

Ibn Ashur, Muhammad At-Tahir. Tafsir al-Taḥrir wa al-Tanwīr. "Exegesis of Liberation and Enlightenment." Vols 30. Tunisia: Addar Attunusiyyāh lilnaashr, 1984. Print.

Ibn Kathir, Abu Al-Fida Ismail, trans. Tafsir al-Qur'ān al-'Azeeem. "Exegesis of the Glorious Qur'an." Vols 10. Riyadh: Maktaba Dar-us-Salam, 2003. Print.

Mawdudi, Sayyid Abul A'la'. Tafhim al-Qur'an: Towards Understanding the Quran. Vols 3. London: The Islamic Foundation, 1988. Print. 
Nasr, Seyyed Hossein, Caner K. Dagli, Maria Massi Dakake, Joseph E.B. Lumbard and Mohammed Rustom, eds. The Study Quran: A New Translation and Commentary. San Francisco: HarperOne, 2015. Print.

Nassimi, Daoud Mohammad. "A Thematic Comparative Review of Some English Translations of the Qur'an." Diss. U of Birmingham, 2008. Print.

Veisbergs, Andrejs. "Paratexts in Translations of Canonical Texts: The Case of the Bible in Latvian". Vertimo Studijos. Vol. 6 (2013): 75-86. Print.

Yuksel, Edip, Layth Saleh al-Shaibanm and Martha Schulte-Nafeh, eds. Quran: A Reformist Translation. United States of America: Brainbow Press, 2005. Print. 